\title{
Degrowth in city planning
}

\author{
ARI AUKUSTI LEHTINEN
}

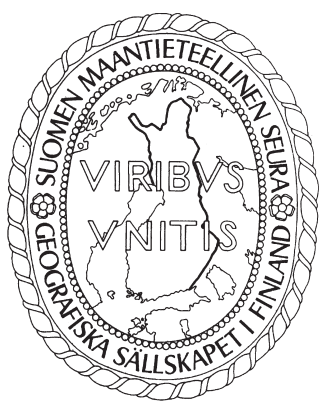

Lehtinen, A. A. (2018) Degrowth in city planning. Fennia 196(1) 43-57. https://doi.org/10.11143/fennia.65443

$\boldsymbol{У}$

This paper summarises the key arguments of degrowth thinking and examines their validity in a city planning setting. The paper argues that much of the reorientation work that is necessary to meet the goals of international climate change conventions needs to be carried out locally, in urban and regional settings, and this creates pressure to renew land-use planning practices. It also argues that in light of the latest carbon footprint studies the currently popular linking of urban planning motives with the doctrine of 'compactness policy' - which aims at urban core densification and accumulation of growth options - needs to be re-evaluated. The empirical part of the paper focuses on the inner city planning of Joensuu, a city in Eastern Finland with 75,000 inhabitants which has increasingly been criticised by some residents, civil servants and civic action groups for one-sided promotion of the central city. This is, according to critics, taking place at the cost of the surrounding countryside and peri-urban nodes. The paper illustrates how the 'tactics of growth' become manifest in the official local planning procedure and to what degree the planning critique, explicitly or implicitly, leans on degrowth concerns. The gathering of the empirical material progressed as part of my involvement in the local degrowth movement, Kohtuusliike, which actively participated in the preparation of the Central Joensuu General Plan 2012.

Keywords: climate credibility, risks of urban compression, decarbonisation, overconsumption, green space, Joensuu

Ari Aukusti Lehtinen, Department of Geographical and Historical Studies, University of Eastern Finland, P.O. Box 111, FIN-80101 Joensuu, Finland. E-mail: ari.lehtinen@uef.fi

\section{Introduction}

Supporting growth has long been the priority and unquestioned motivation of urban planning. Urban growth is most often associated with population increase and rising employment rates, and it also regularly refers to the extension of local entrepreneurial activities and turnover rates. In addition, the diversification of services and consumption options are generally regarded as positive growth signals, as is the overall strengthening of inter-local competitiveness. Moreover, the ranking of cities as a rule rewards growth production and stigmatises those that fail to grow as second-class cities.

The more recent pressure of decarbonising city functions has added an element in urban growth planning. Today, as goes the much-purported argument among city developers, growth needs to be spatially compressive and accumulating in order to minimise the carbon footprint of daily urban operations. Compact cities and densely built city centres are regarded as climate friendly. Accordingly, climate concern has become established as the explicit rationale for densifying regional city dynamics (Newman \& Kenworthy 1989; Kenworthy 2006; Dodman 2009; Haarstad 2016; Sireni 2016; 
Haarstad \& Oseland 2017). However, some recent studies on the changes of carbon emissions caused by urban compression have shown that the actual footprints do not necessarily follow the initial thesis. Climate strain seems to grow when populations are concentrated due to changes in consumption patterns. Urbanisation comes across as resulting in increasingly consumptive lifestyles with increasing levels of carbon emissions. This change seems to exceed the possible reductions of carbon emissions caused by the (estimated) decrease in mobility during urban densification (VandeWeghe \& Kennedy 2007; McLean et al. 2015; Ottelin et al. 2015; Lehtinen 2017a).

This compression critique has not influenced on the preferred trends in urban planning. In general, growth is still the primary objective, though in a highly selective form: favouring concentrations of population and consumption. It is widely believed and argued that spatial growth accumulation promotes decarbonisation. Degrowth has not been accepted as a serious alternative despite the widening academic and public debate arguing for it (Gorz 1979; Victor 2008; Jackson 2009; Latouche 2009). The necessity of reductions in urban consumption has therefore not been regarded as central in mainstream urban planning.

This is, however, a remarkable area of tension in contemporary city development. The dominating doctrine argues that decarbonisation is possible by promoting growth accumulation whereas critics say there is no empirical proof for such a linkage. Instead of growth plans, critics favour transition programmes that focus on lowering carbon emissions by diminishing the throughput of energy and matter (e.g. Harribey 2011; Mälgand et al. 2014; Barr \& Pollard 2017). Decarbonisation, they say, is not possible when the overall and per capita throughput is increasing, and this seems to be the case in growth centres.

This leads to a number of important questions. Why do the promoters of growth lean on and utilise climate concerns rather simplistically? In what way is the growth-critical opposition taken into consideration? What about the climate credibility of growth planning? What kind of motives, rhetoric and techniques can be singled out while studying the tactics employed under the dominant doctrine? How does the degrowth opposition successfully argue for the transition to reduce the throughput of energy and matter?

The present study answers these questions by first summarising the main points of degrowth thinking, especially in relation to urban compression and climate change responsibility. Second, the paper uses an empirical analysis of growth planning in Joensuu, a city of 75,000 inhabitants in Eastern Finland, and the opposition to it to focus on degrowth issues. Finally, the confrontational setting is distilled, focusing on the priorities and tactics of compressive growth vis-a-vis the demands and promises of degrowth planning.

\section{Arguing for degrowth}

Degrowth, or the post-growth agenda, is a critical research and action programme that questions the background premises and dominant emphases of the growth society. It has grown and spread steadily during the last 15 years and has recently been labelled as the "rebirth of a radical environmentalism" (Kallis \& March 2015, 360). Degrowth scholars and activists aim at freeing the political sphere from the dominant economic thinking which, "links prosperity exclusively with continuous growth in materially and monetarily measurable economic performance" (Schulz \& Bailey 2014, 280). Moreover, economic growth is criticised for being the only acceptable rationale in urban planning, leading to the impression that local solutions remain non-communicative with concerns about the planetary limits that humankind is currently facing (see Bailey et al. 2010; North 2010; Graugaard 2012).

The degrowth critique is generally sceptical toward programmes of urban compactness policy that promote forceful rebuilding. It is concerned that the central areas under compression will become densely built and lose their green spaces and older layers of urban architecture while the estate values on the fringes of such centres will decline. The degrowth movement is critical of the fundamental divisions of labour between areas of intense redevelopment and areas with decaying infrastructure. Consequently, degrowth's concern is easily linked to the support of autonomy and relocalisation, and against the exacerbation of dependencies (Latouche 2010, 521; Kallis et al. 2015, 8). 
In addition, degrowth advocates have insistently pointed out the key fallacies of the growth doctrine. They argue that once economic growth reaches a certain stage, it fails to increase welfare and employment. This threshold was, according to them, already reached in the 1970s and 1980s in many countries of the developed world (Schneider et al. 2010, 512; Eskelinen 2011; Papadopoulou 2011, 18-19; OECD 2015). Furthermore, they have illustrated that belief in qualitative growth decoupled from environmental degradation is based on false presumptions. On the contrary, upgrading human prosperity has always and everywhere, without exceptions, resulted in expansive strain on the environment (Schneider et al. 2010, 512; Schulz \& Bailey 2014, 280; Kallis et al. 2015, $6-7)$. It is also argued that facts against this rule are simply the result of statistical weaknesses like, for example, the exclusion of carbon emissions caused by imported energy and goods (e.g. Heinonen \& Junnila 2012; Ottelin et al. 2015).

Moreover, instead of reiterating the overall risks and outcomes of global population increase, the degrowth critique shows that almost half of private carbon emissions are due to the overconsumption of the richest $10 \%$ of humankind (Oxfam 2015; Joutsenvirta et al. 2016, 156). Degrowth thinking also attacks the fallacy of the effectiveness of mainstream growth by arguing that the actual rise of effectiveness in the contemporary world can only be achieved by diminishing the use of energy and material, and through their equitable division (Kallis et al. 2015; Joutsenvirta et al. 2016).

Furthermore, degrowth scholars argue that the goals of actual effectiveness and consumption decrease can only be achieved by strengthening political regulation which leans on forceful tariff and tax policies, adequate environmental licensing and emission limits. This type of policy should specifically target major exploiters and polluters (Joutsenvirta et al. 2016).

Degrowth thinking is hence firmly grounded in the vision of a society which consumes less natural resources. It aims at the equitable downscaling of production and consumption resulting in radical reductions and reorientations of the overall metabolism of societies. The focus is on qualitative changes that prioritise questions of health and education. It supports policies grounded on broad socio-environmental responsibility, especially developing welfare work and the reproductive practices of sharing and caring, which also extend to non-human communities and environmental restoration concerns (Kallis et al. 2015). It therefore aims at profound social change based on environmental citizenship, politics of relocalisation and the economy of the commons (Brangsch 2011, 63-64; Eskelinen 2011, 12; Kallis \& March 2015, 366).

Degrowth strategies prioritise local transitions that reduce energy and material consumption, which are claimed to yield reductions of import costs and enhance self-sufficiency. In addition, urban degrowth prefers pedestrian safety, extensive bicycling networks and well-functioning public transportation. It also creatively utilises the existing floor spaces of housing, retail stores and offices (Joutsenvirta et al. 2016, 170-171).

Consequently, local degrowth initiatives resonate well with urban transition campaigns aiming at low carbon communities (Mälgand et al. 2014; Schulz \& Bailey 2014; Barr \& Pollard 2017). Degrowth and transition movements foster local actions that reduce environmental impacts, energy consumption and carbon emissions; they both also concentrate on the renewal of urban mobility infrastructure. Much emphasis is cast on social innovations developing affordances that help households free themselves from the strains of privately-owned automobiles. Mobility is then increasingly regarded as a service (Kanninen et al. 2010; Kamargianni et al. 2015). Similarly, both in degrowth and transition campaigns, the determinism of evermore housing space per capita is challenged by neighbourhood and household level initiatives that creatively re-design rooms for housing (D'Alisa \& Cattaneo 2013; Cattaneo \& Gavalda 2015; Lietaert 2015).

As part of this renewal, land-use planning is seen as an instrument that can and needs to be developed into a means that supports qualitative maintenance and upgrading. It is argued that this type of qualitative turn in land-use planning offers a feasible alternative to the still largely dominant volume-orientation in urban development. The indoor and outdoor spaces of city centres are, in the degrowth reorientation, primarily regarded as multicultural arenas, meeting places, and attractive areas of dwelling, instead of competitive growth motors that fuel general economic prospects by steadily raising consumption demands. City planning is thus fundamentally divorced from its current associations to volume production (Lehtinen \& Pyy 2017). 
The degrowth planning initiatives focus on and invite these changes in the cultures of mobility, housing and consumption. It is argued that this alternative, though still sporadic and contingent, actually exists and unveils pathways of decarbonisation. It is also underlined that the suggested transition would radically redefine the ideologies and practices of urban planning (Joutsenvirta et al. 2016, 170-171).

\section{Studying degrowth conditions in Joensuu}

The empirical part of this study was conducted by identifying the formulations that take a stance on growth versus degrowth issues from the land-use policy debate in Joensuu. Particular attention was paid to the intersections of the dominant and opposing planning argumentations and their positioning in the Master Plan procedure. The method chosen here is an application of critical reading, or contrapuntal reading, where the researcher identifies both the explicit topics and the hidden or poorly communicated themes in the studied material. In this way it is possible to formulate the more general societal and ideological setting informing the different articulations, but this also enables the composition of nonconformist angles to the specific setting under research. This type of reading thus extends to poorly communicated issues, or those that are entirely ignored by some key stakeholders (Said 1991, 1993, 59-60; Pöysä 2010; Sawatzky 2013; Kaakinen \& Lehtinen 2016).

The critical reading was divided into four phases. First, the main thematic hot spots were identified and described, including the dialogical dynamics attached to tensions in compactness policy, landuse intensification, traffic planning, architectural change and green spaces in Joensuu. Second, the episodes of non-communication were pointed out and documented, both externally in relation to opposing stakeholders and internally in the form of ruptures and decoupling between the agreed upon planning goals and their implementation. Third, signs of non-verbalised or non-reflected production of urban growth were collected, and the tactics of decoupling extracted from within the evidence already presented. Finally, the explicit and implicit linkages to degrowth alternatives were gathered from the arguments of planning critics.

The empirical material consists of the Master Plan documents, the written civic statements and comments, the juridical complaints and court decisions concerning the Master Plan, and the planner's written responses to critics. In addition, the local media debate linked to the planning procedure was utilised.

The practical participatory part of the study progressed as part of my involvement in the local degrowth movement, Kohtuusliike ${ }^{1}$. I was involved as an expert on land-use planning and as the secretary of the planning group of the movement during the preparation of the Master Plan (MP) (2010-2012) and in the subsequent juridical process addressed to the Regional Administrative Court (RAC). As the secretary of the planning group, I wrote the movements's statement to the MP's goal formulation (20 Dec 2010), the statement to the MP draft (13 Feb 2011) and the reminder to the MP proposal (5 Oct 2011). During the court process, I wrote the juridical claim (16 Jan 2013) and response (19 March 2013) to the court statement by the municipal planner who had reacted to our complaint. Participation in the planning process included active involvement in MP briefings from 2010-2012 (Lehtinen 2014a, 2014b).

\section{Growth planning and degrowth initiatives in Joensuu}

Radical restructuring of the inner city of Joensuu was launched in 1962 by a detailed plan which promised thorough modernisation. The traditional wooden town was to be completely rebuilt as blocks of flats, with four storeys being the preferred standard. This is what occurred during the following decades and central Joensuu gradually acquired a uniform appearance. This restructuring resulted in the concentration of approximately 10,000 inhabitants in the inner city of about $1.5 \mathrm{~km}^{2}$.

In the early 1990s it became obvious that the land-use intensity of the city centre had been left too low. International trends, driven by climate change concerns, promoted densification and complementary building. In Joensuu, compressive planning was adopted as the key content of sustainable development, and it also served as the justification for tearing down the last 
remaining wooden houses that had not gained conservation status in the city's core (Nevalainen 2004, 170-174).

The compression planning turned into a new phase of intense redevelopment in the early 2000s, and the boom has not shown any signs of weakening since. On the contrary, the spatial growth accumulation strategy was reinforced from 2010-2015 in the Master Plan process.

The intense and multiphase planning process ended in the Supreme Administrative Court of Finland, which finally rejected all juridical complaints in 2015. The lengthy campaign, as was then summarised by the critics (Lehtinen 2014a, 2014b), resulted in only one minor, if symbolically important, success in the Regional Administrative Court: the intention to tear down the Wanha Jokela restaurant building was deemed illegal (Fig. 1, see also Hurskainen 2011; Rautio \& Longi 2013).

According to the Master Plan, compressive growth in Joensuu is to be conducted by remarkably increasing the land-use intensity and automobile use in the inner city. The aim is to add residential attractiveness and commercial competitiveness to the centre. Densification is to begin through inventories of building potentials both in already-built areas and in green spaces. In addition, traffic problems are to be solved by establishing a dense network of roundabouts encircling the planned underground parking hall below the central market square. Moreover, as an extension to the Master Plan, the central railway station area at the eastern end of central Joensuu is to be filled with blocks of flats earmarked for commercial, office and residential purposes (Fig. 2).

In contrast, juridical complaints about the Master Plan focused on the costs of continuous compression, especially the loss of green spaces and older layers of the city centre ${ }^{2}$. These complaints were formulated by groups that were highly involved in the Master Plan process, such as local nature conservationists (Joensuun luonnonystävät), Kohtuusliike and the Pro-Wanha Jokela Movement. In addition, many individuals were also active in writing complaints about the planned riverside land-use.

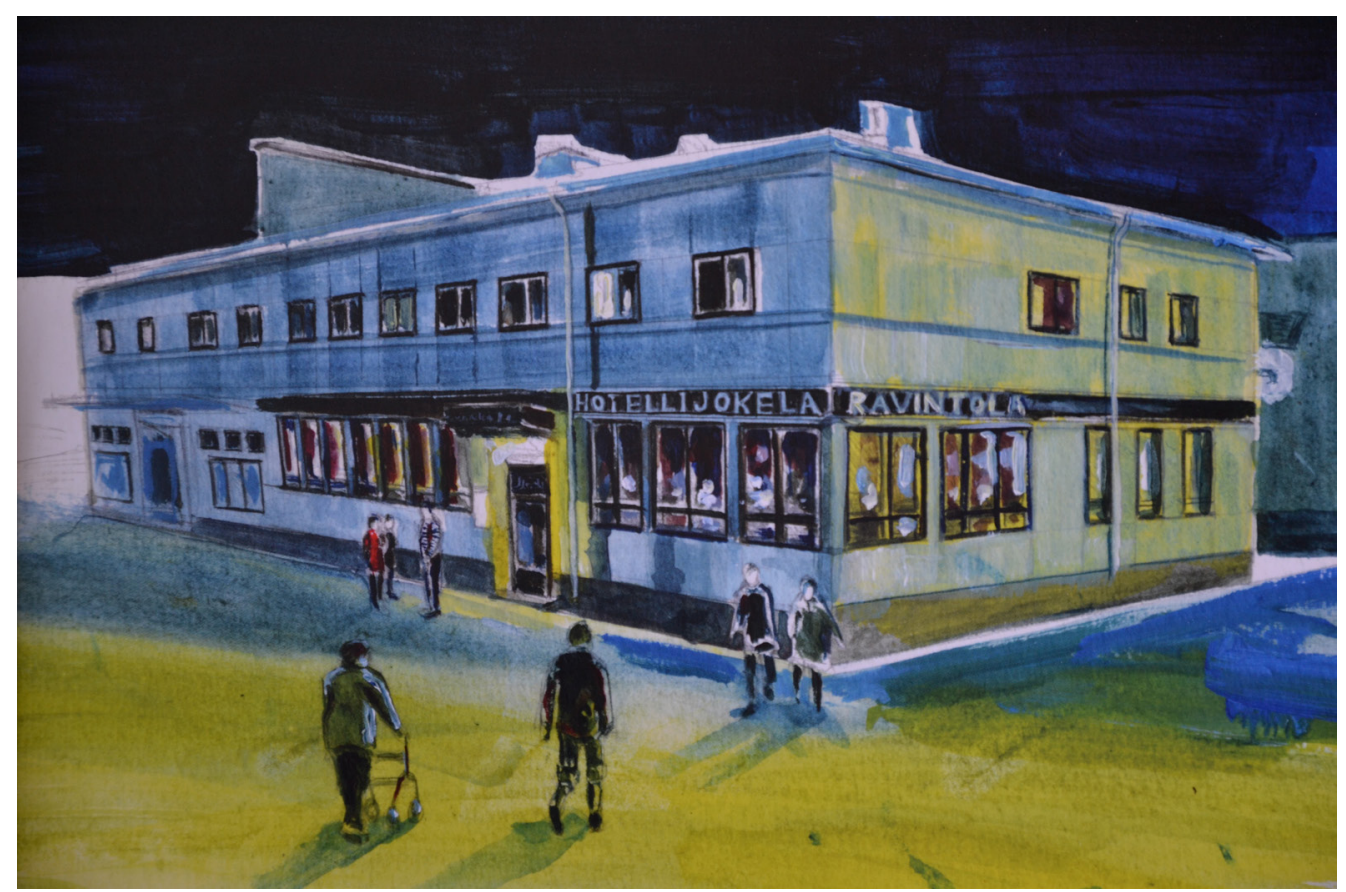

Fig. 1. The Wanha Jokela Restaurant building, closed since 2012, returns to the agenda in 2018 - as an issue of detailed planning. The painting by Heli Kemiläinen decorates the cover of the album Turha kylä ilman Jokelaa (Pilfink Records 2011). The album contains 17 songs by Finnish musicians supporting the restaurant. Copyright Anita Latola. 


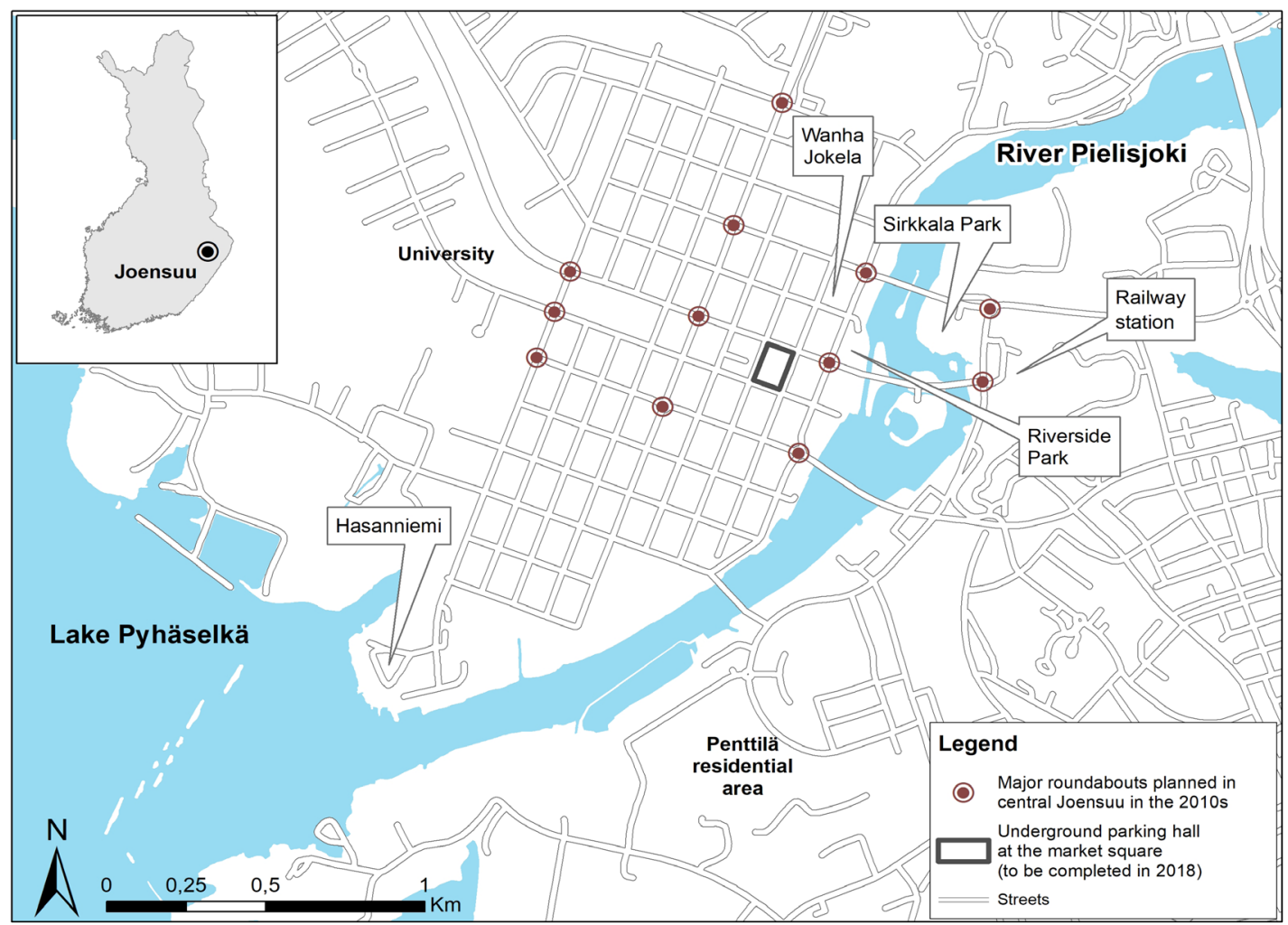

Fig. 2. Major planning disputes in central Joensuu in the 2010s. Copyright Noora Rämö. Contains data from the National Land Survey of Finland Topographic Database 03/2018

Questions of degrowth were explicitly argued by Kohtuusliike during the planning process. In addition, those participants who emphasised issues of environmental or cultural conservation often, more or less implicitly, returned to concerns of overestimated development options causing damage to historical city architecture and green spaces. In general, the degrowth critique attempted to redirect and repoliticise the planning debate, which otherwise tended to favour technical and isolated features, such as individual buildings and building options, traffic arrangements in specific locations and the riverside hot spots.

Degrowth thinking also surfaced in statements defending common outdoor and indoor spaces, such as parks and the Wanha Jokela restaurant milieu, from intrusive land-speculation. Finally, during the planning process Kohtuusliike repeatedly returned to the planner's rationales for remarkably adding housing and commercial space, and automobile intensity to the inner city. According to Kohtuusliike, planning ought to follow the climate and energy commitments signed by the city and favour solutions which guide the public towards lessening community-specific consumption of energy and goods. Growth emerging, for example, from rising local throughput resonates poorly with the latest planetary conventions. The Master Plan largely ignored the transition duties facing individual communities and the humankind in general.

Kohtuusliike starkly questioned the plan's realism. The expectations bound to increases in population and consumption trends largely ignored the local and provincial prospects, which do not promise much growth in the city. Moreover, the one-sided favouring of the city's core was regarded by the Kohtuusliike Movement as regionally irresponsible while undermining the wishes of the smaller provincial centres in North Karelia. 


\section{Tactics of growth}

The episode in Joensuu described above is a telling example of the poor planning coordination that handed decision-making power in the most central planning questions to juridical experts. For most of the participants in the planning process it must have been annoying that judges of the administrative courts had to be called upon to solve local planning problems.

The critics generally felt that active civic participation in the Master Plan's goal formulation, drafting and proposal-making resulted in nothing. Planning was, according to the critics, forwarded by the city planners without serious willingness to engage in reciprocal co-management - which is a central imperative in the Finnish Land Use and Building Act (LBA, see Ekroos \& Majamaa 2005). The number of juridical complaints, initially nine to the Regional Administrative Court (RAC) and then eight to the Supreme Administrative Court (SAC), highlights this collective civic disappointment ${ }^{3}$.

Why did the planning process fail to such an extent that the court cases became unavoidable? The politics of compression in Joensuu, ongoing since the 1990 s, clearly provoked the juridical complaints. Active citizens, who had long followed the city planning performance in Joensuu, finally had to rise up and speak their voices to question the reasonability and limits of such straightforward urban densification. These critics mainly reacted to individual planning details but they also questioned the general trend dominating city planning. In addition, the necessity to change the entire planning ideology in Joensuu was pointed out and reasoned (RAC 2014).

The high number of juridical complaints reflects the broad feelings of disappointment among the critics but it also reveals the weaknesses of the planning process. It was thought that the planning authorities had misinterpreted the imperative of direct participation, the right of citizens to be involved, emphasised in LBA (Bäcklund 2002; Bäcklund \& Mäntysalo 2010). Listening to critical voices was limited to formal hearings where the agenda was carefully designed beforehand by civil servants and staff members of the private consulting company (at the request of the city planning authorities). The number and diversity of the critical voices led the city planners towards an easy solution. "All concerns could not be taken into consideration," replied the Joensuu city planning office to the juridical complaints (Joensuu 2013, 7). This banal factum contained the connotation that the planner can decide whose voices deserve to be taken into consideration. The power to rank voices strengthened the city planner's own voice.

Due to shortcomings in direct participation, the social licence of the planning procedure rested on the democratic vigour of representative participation. The elected members of the city council and board controlled the progress of planning and commented on the draft and the Master Plan proposal. However, the long and technically demanding process made it difficult for local politicians to keep an eye on the plan's advancement. The political mandate rested on the skills, courage and schedules of individual council and board members (Lehtinen 2014b, 125).

The contested interface between the town planning staff and citizens, including their representatives, shows the bearing of local democracy. On one hand, from the side of the authorities, planning is undoubtedly demanding as it has to progress despite the tensions and contrasting pressures attempting to influence it. The plurality of town concerns has to be reduced into a compromise, a kind of single model that can be defended during the years of planning and implementation. The defence of the reductions, quite understandably, becomes a contest over authority (Rajaniemi 2006). Decisions and agreements once made result in 'artefacts' that, from the participants' points of view, tend to freeze the planning procedure (Jokinen 2005).

In Joensuu, the planning authorities seem to have frozen the local implementation of climate concerns into a prior model of densification. The compression of the inner city is said to serve the purposes of decarbonisation and its defence is grounded on the compromises initially made in the 1990s. Scientific evidence (VandeWeghe \& Kennedy 2007; McLean et al. 2015; Ottelin et al. 2015) has shown the fragility of such a compromise but the model is still regarded as the core doctrine of city development in Joensuu. This frozen setting has been noticed by critical researchers who have brought up the question of hidden motives of inner city densification. Compressive planning, in practice, favours land developers' private motives at the cost of green spaces and historical architecture (Kortelainen \& Vartiainen 2000). 
The Master Plan process (2010-2015) confirmed the existence of tactical decoupling ${ }^{4}$ as climate concerns were favoured only when they supported other Master Plan goals. City compression, explicitly motivated by local decarbonisation, results in inner city restructuring which supports the financial aims of land developers. This linkage is confirmed by land-use agreements made between the planning authorities and private developers before the public planning procedure was launched (Lehtinen 2017a). Decoupling in Joensuu planning offers a vision of spatially accumulating growth that is good for the planetary climate. This is to be achieved by significantly densifying the inner city, both for housing and commercial purposes. In addition, automobile use is encouraged in the inner city due to prognoses relying on the continuity of traffic growth witnessed in the past. Hence, if we follow the explicit argumentation of the planning authorities, decarbonisation is to be carried out by making Joensuu's downtown an increasingly attractive and consuming growth centre in North Karelia.

This tactic, when examined through the lens of decoupling, serves the dominant trends and private financial interests. The planning profession is, in this respect, reduced to operative guidance which primarily adjusts to dominant and estimated development pressures. The guidance and controlling potential of planning is lost. In this light, the practices of direct and representative participation serve as a veil or mask ${ }^{5}$ that both conceals and legitimises the already-agreed upon, and frozen, governance of the city. Participation becomes a ritual which has no significant influence on the end result. This is disturbing, especially when contrasted with the imperatives of LBA, which demand that the planning authorities carefully listen to the concerns emerging from participation, both direct and representative, and proceed in the planning task accordingly.

In order to utilise participation as a mask, the planner is obliged to continuously renew the tactic that maintains the decoupling. The following manoeuvres, or tricks, were utilised in the operative conducting of the Joensuu Master Plan. First, decoupling dissociated the general goals from practical priorities in traffic planning. In general, at the level of goals and during the entire planning process all forms of transportation were said to be treated equally. In practice, however, the quick promotion of roundabouts and general fluency of private driving in the city centre soon revealed the hidden priorities. This meant that citizens could not raise their concerns during planning as there was no reason to comment on the balanced goal setting. And then, afterwards, protests were simply too late.

Goal setting casting equal weight on all modes of transportation could surely be criticised from the start as being unjust due to the long history of favouring automobiles in Joensuu. As the ease of driving private cars has been the primary motive for at least half a century in the city, including its central parts, equalisation would now mean first supporting pedestrians and bicyclists as well as public transportation. In addition, especially if following some international spearheads of urban mobility renewal (Kamargianni et al. 2015; Barr \& Pollard 2017), the equalisation of traffic in Joensuu would also require effective limitations, taxation or fees on private driving.

Cycling development is perhaps the most striking example of tactical decoupling in Joensuu. The town is famous for the popularity of its year-round cycling and this practice is broadly advertised in the official marketing of the town. However, only a few kilometres of cycling paths exist in Joensuu's centre. Most cyclists therefore use those paths that are assigned to all non-motorised vehicles or alternatively, and at their own risk, join car lanes. The popularity of cycling in Joensuu is mainly due to poor public transportation conditions: the bicycle is, in fact, a year-round necessity for many inhabitants (Lehtinen 1997; Pyy 2017).

Second, the Pielisjoki River, which runs through central Joensuu, also became tactical material for the Master Plan promoters. The densification of the central city is highly focused on sites by the river. Blocks of houses were proposed to be situated in central locations along the river, which is a landscape of national importance according to the Finnish Heritage Agency and the Government of Finland (Lehtinen 2014a, 121). In addition, the detailed planning during and immediately after the completion of the Master Plan incorporates the opposite shore of the river into intense development. Blocks of houses and high-rise towers from 12-14 storeys have been proposed. Apartments in highrise blocks with views over the river are attractive for private developers due to the potential maximum financial returns per square metre. Construction businesses move towards centres of growth and the question of Joensuu's position in intercity growth ranking is broadly seen as directly reflecting the skills of the planning apparatus. Growth is therefore the only alternative for the 
planning authorities, and it is to be achieved, for example, at the cost of those centres and regions below any growth options.

Growth contestation in Joensuu has resulted in a series of land-use agreements between developers and the planning authorities. These contracts condition the public procedures of planning and they also force the planner to develop tactics clever enough to confirm their a priori agreements in the final plan document. This dependency, and tactic, was masked in the Pielisjoki riverscape planning through the vision of a symmetrical town with equal development on both shores of the river. The promise of symmetry convinced citizens and their representatives to such an extent that no broader doubt emerged, for example, about the consequences of the growth scenario or its reliability in general.

Third, the planning tactic was set forth in the development of the green spaces of Hasanniemi, the southern peninsula of central Joensuu at the mouth of the river. The aged forest area in the centre of the peninsula is planned to be significantly reduced by a housing development and general infrastructure expansion, despite widespread civic resistance which first emerged in the late 1990s and again during the Master Plan process. The civic concern in both episodes arose from the fear of losing the only forest area in central Joensuu, which has served as an important outdoor recreation target for local residents for a long time.

The planning authorities reacted to the first wave of critics by withdrawing from the housing development in the 1990s but returned to the issue as part of the Master Plan. This time the response to concerns was clothed in an ecological inventory which showed that no species under the risk of extinction could be found in the immediate area proposed for housing (Joensuu 2012, 18). The move was an excellent example of non-communication in environmental planning (Kaakinen \& Lehtinen 2016). The subsequent decision to continue housing and infrastructure development in the area forced the critical citizens to take the case to court. Three of the nine juridical complaints brought to the Regional Administrative Court raised the question of the development of the Hasanniemi forest.

The tactic of ignoring the outdoor recreation concerns and, instead, focusing on species at risk was successful as all the complaints were rejected in the Regional and Supreme Administrative Courts. The court's explicit justification emphasised that the planned development area is small (e.g. 7,500 $\mathrm{m}^{2}$ for housing) and that the Koivuniemi park nearby meets the demands for local outdoor recreation well enough (RAC 2014). The Court thus equated the recreation values of the aged, uneven stand of forest in Hasanniemi with those of the Koivuniemi park, which has a younger, even-aged stand of trees.

Consequently, the Hasanniemi forest is currently being drawn into the detailed planning and the proposal now aims at an expansion of the number of single houses, increasing the initial five to eight building sites up to ten. However, the discovery of a nesting couple of highly threatened whitebacked wood-peckers (Dendrocopos leucotos) near the planned housing area was made public in December 2017 (Kauhanen 2017). City planners have not reacted to this news but, as the nest is not inside the defined development area, detailed planning most likely continues unaffected. This would be in accordance with the conclusions of the earlier inventory results which stated that, "no species under the risk of extinction could be found in the immediate area planned for housing construction." (Joensuu 2012, 18)

However, the Hasanniemi conflict clearly illustrates the planning authorities' intention to use the city centre's green spaces, even the most central and valued aged forest, as a reserve for its compactness policy. The general goal of town compression seems to legitimise the reduction of those outdoor recreation amenities that have been starkly defended by the inhabitants. Alternatively, as was worried in a local publicity (Olli 2012), the planning authorities have already agreed to offer these highly attractive building sites for private purposes. However, no proof of an a priori agreement could be found in planning documents.

\section{Discussion: toward degrowth planning}

The compression policy in Joensuu can, as was done above, be evaluated as a tactical performance or a systematic decoupling operating with hidden priorities, mask constructions and acts of noncommunication. However, city compression can be situated in a more general setting where it is 
linked to both local environmental concerns and international policy pressures demanding actual progress in decarbonisation.

Densification that results in shrinking green spaces in the city core is incompatible with climate policy favouring urban parks, forests and individual trees as elements that provide shelter from strong winds and intense periods of heat. Green spaces in the city centre also offer easy access to nature for all citizens, including those without their own car to drive to more distant outdoor recreation areas.

Accordingly, city development that seriously promotes climate responsibility would not easily allow building to expand at the expense of green spaces. It would, instead, concentrate on those building sites already partially occupied. The fact that the planning authorities in Joensuu have disagreed with this and, on the contrary, allowed significant building pressure to be directed towards the riverbanks and the Hasanniemi forest highlights the policy tactics adopted. Concern for climate issues informs planning when it supports other aspects of city development. In other words, climate policy submits to spatial growth accumulation.

The question here is about the climate credibility of the city's development. Despite active civic pressure, planning in Joensuu has not contained much environmental innovativeness or many proclimate acts. This gives the impression that local development has been rushed only to have it completed before more restrictive climate policy is introduced via international conventions, especially as part of EU policy measures.

Currently, it seems that the city planning authorities are waiting for guidance from above and the citizens' concerns have not weighed enough to influence a major turn in city development. Moreover, the frozen setting of planning is also impervious to those critically innovative voices that have arisen from within the city administration itself. Joensuu is participating in a nation-wide decarbonisation programme, which aims at reducing 80\% of local climate emissions from 2007 to 2030 (PKM 2016). This commitment, however, does not seem to concern the planning authorities investing in city compression, the fluency of private automobile driving, consumption increase and growth accumulation, or, in one word: throughput. This is a sign of decoupling and non-communication within the city administration ${ }^{6}$.

Despite their largely critical tone, the opponents of the Master Plan 2012 process also included suggestions for alternative development in Joensuu. Instead of the one-sided favouring of the city core, the critics would strengthen the existing composition of a regional city by maintaining and developing the existing polycentral infrastructure on an equal basis. This type of planning would be developed by improving the general liveability and environmental quality of the centres and areas surrounding the major core. In this case, the mobility services of the areas and between the regional centres would also be strengthened to such an extent that the need for private cars would decrease. The degrowth concern of the critics hence favoured respectful maintenance and slow renewal of the existing polycentral regionality, supported by innovations in mobility services. Intense redevelopment due to urban compression was deemed a social and ecological burden.

In addition, the critical statements on traffic planning included advice on effective equalisation of inner city mobility. Instead of prioritising private automobile fluency in the city's core, the city planners were asked to promote the conditions of public transportation, pedestrians and bicycling. Rather detailed traffic plan suggestions were formulated in the official Master Plan briefings. The degrowth planning initiatives were explicitly grounded on an aim to advance just mobility but at the same time they were broadly aware of the optional pros of reducing the use of private automobiles, both at the level of the city and within individual households.

Moreover, the critics seemed to highly appreciate the layered composition of downtown Joensuu, both in terms of architecture and greeneries. The Master Plan critique emphasised the idea of a city that appreciates the historical merits of its present make-up. A unique city core was favoured, instead of intense densification motivated by general growth accumulation options and intercity growth-rankings. A shift away from volume-orientation toward qualitative planning was proposed, aiming at the upgrading of the daily living conditions. The degrowth thinking here was associated with an emphasis on qualitative city renewal - which, if applied and developed systematically, would result in a thorough change to the city's planning culture. 
The alternative plan for Joensuu, when reconstituted from the comments of the Master Plan's degrowth critics, is clearly grounded on an understanding that the upward trends in city compression and consumption must be reduced. The primary motive arises from climate and environmental concerns but it is also informed by the awareness of the major causes of the problems in the city's overall economy: the vulnerability of a city deeply mired with overconsumption. The critics thus argue that degrowth planning can be used as a means to balance the local budget deficit caused by rising import and overconsumption costs - it can be seen as a tool to critically examine the constituents of local throughput.

Finally, the presence of the rather broad critical front stood as a request to radically renew the local planning culture. The opposition, based on its sole active presence, seemed to demand the thawing of the frozen planning setting. City planning, the critics argued, should be developed out in the open and without hidden contracts, tactical manoeuvres and systematic non-communication. Planning should move towards co-planning where openly debated disagreements are seen as enriching the process. The voices of the critical front hence contained a call for adding transparency and inclusiveness in the planning of Joensuu. In broader city planning literature this type of forwardlookingness is sometimes called agonistic planning (Bäcklund \& Mäntysalo 2010; Rannila \& Loivaranta 2015; Bäcklund et al. 2017). Degrowth politics, in other words, cannot be separated from the orderly unmasking of central city planning dependencies.

\section{Notes}

${ }^{1}$ Kohtuusliike was launched in 2009 to promote cultural, political and economic changes that result in the decreased consumption of natural resources in North Karelia. The movement has aimed at initiating degrowth alternatives that support moderate ways of thinking, decent ways of living and socio-environmentally just solutions. As part of this work, the movement has participated in regional development and planning debates concerning the future of the province. The emphasis of degrowth issues is central to the movement and it is greatly inspired by similar international initiatives. Kohtuusliike can accordingly be seen as a local actor within a broader international degrowth movement (http://www.kohtuusvaarassa.com/).

${ }^{2}$ Five of the nine complaints addressed central land-use planning issues. In addition, the democracy of the Master Plan process was questioned by Kohtuusliike. The remaining complaints were restricted to private property issues, such as strains on individual land owners due to the plan (RAC 2014). The continued complaints to the Supreme Administrative Court were reduced to eight as Kohtuusliike regarded its complaint as not being valid enough for further elaboration. Moreover, the planning authorities of Joensuu did not see the court decision (deeming the plan to tear the Wanha Jokela Restaurant building illegal) as worth bringing to the Supreme Administrative Court. However, the fate of the building will become an issue of detailed planning in 2018.

${ }^{3}$ The number of planning complaints linked to the Master Plan processes was high compared to the average in Eastern Finland, which varied from one to four from 2013-2015 and were only connected to the most heated questions (RAC 2016). Of course, most planning decisions never go to court. Those citizens who are active in city planning and are disposed to proceed all the way to court represent only a small minority of the population in Joensuu. This is also often underlined by the city planners. In this way the planners stigmatise active citizens: instead of regarding them as enriching planning, they are seen as a nuisance delaying the process.

${ }^{4}$ Tactical decoupling here refers to the tendency of political and planning activities to support dominant practices while explicitly aiming to solve problems that are in fact created under the dominant conditions. Decoupling may be developed into systematic divergence between political intention and effect (Donner-Amnell et al. 2004, 268; Lehtinen 2012).

${ }^{5}$ The interpretation of participation as a mask has been documented by Jussi Semi (2017) in a suburban planning context. He identifies episodes of official framing where promoting participation is channelled to produce increasingly competitive individuals and neighbourhoods to strengthen overall competitiveness. Participation is not primarily regarded as something valuable in itself. Participation can also be developed to serve as a means to soften and hide actual injustices in 
administration and policy routines. Mask construction can be seen as a decisive element in tactical decoupling 4 .

6 The calculations of decarbonisation in Joensuu follow the general guidelines provided by the International Panel on Climate Change (IPPC) and Finnish Environmental Centre (SYKE). They advise local actors to refrain from counting the major share of those carbon emissions from international production and transportation chains that are caused by, for example, local consumption of groceries and consumer goods (Ottelin et al. 2015; Joensuu 2016; Lehtinen 2017b). This exclusion has resulted in the impression of local growth economies being able to become climate-friendly. Consequently, the local climate programme has recently become a growth-legitimating element in Joensuu (http://www.joensuu.fi/ilmasto-ohjelma).

\section{Acknowledgements}

I owe a major debt to the activists of Kohtuusliike for co-participating in the Joensuu Master Plan procedure and causing the degrowth issue to become an important question in the Plan preparation. In addition, warm thanks are due to Merja Maukonen, Ilkka Pyy, Jussi Semi and Jenna Taajamo, my partners in the 'Symmetric City' research group (2015-2018), for intense debates significantly upgrading the content of this paper. Thanks are likewise due to Matthew Sawatzky for correcting my English and Noora Rämö for drawing the map of Joensuu. Finally, I also thank the two anonymous reviewers for their comments on the paper.

\section{References}

Bäcklund, P. (2002) Miten kuulla asukasta? Kaupunkitila ja osallisuuden haasteet. In Bäcklund, P., Häkli, J. \& Schulman, H. (eds.) Osalliset ja osaajat. Kansalaiset kaupungin suunnittelussa, 141-157. Gaudeamus, Helsinki.

Bäcklund, P. \& Mäntysalo, R. (2010) Agonism and institutional ambiguity: ideas on democracy and the role of participation in the development of planning theory and practice - the case of Finland. Planning Theory 9(4) 333-350. https://doi.org/10.1177/1473095210373684

Bäcklund, P., Häkli, J. \& Schulman, H. (eds.) (2017) Kansalaiset kaupunkia kehittämässä. Tampere University Press, Tampere.

Bailey, I., Hopkins, R. \& Wilson, G. (2010) Some things odd, somethings new: the spatial representations and politics of change of the peak oil relocalisation movement. Geoforum 41(4) 595-605. https://doi.org/10.1016/j.geoforum.2009.08.007

Barr, S. \& Pollard, J. (2017) Geographies of transition: narrating environmental activism in an age of climate change and 'Peak Oil'. Environment and Planning A 49(1) 47-64. https://doi.org/10.1177/0308518X16663205

Brangsch, L. (2011) Economic "indicators" are really about power. Political dimensions of object and method in debates on growth. Transform! European Journal for Alternative Thinking and Political Dialogue 3 44-60. <https://issuu.com/nextyearcountry/docs/transform_newsletter_3_2011_01>. 23.01.2018.

Cattaneo, C. \& Gavalda, M. (2015) The experience of urban squats in Collserola, Barcelona: what kind of degrowth? Journal of Cleaner Production 18(6) 581-589. https://doi.org/10.1016/j.jclepro.2010.01.010

D'Alisa, G. \& Cattaneo, C. (2013) Household work and energy consumption: a degrowth perspective, Catalonia's case study. Journal of Cleaner Production 38 71-79. https://doi.org/10.1016/j.jclepro.2011.11.058

Donner-Amnell, J., Lehtinen, A. \& Saether, B. (2004) Comparing the forest regimes in the conifer North. In Lehtinen, A., Donner-Amnell, J. \& Saether, B. (eds.) Politics of Forest. Northern Forestindustrial Regimes in the Age of Globalization, 255-284. Ashgate, Aldershot.

Dodman, D. (2009) Blaming cities for climate change? An analysis of urban greenhouse gas emissions. Environment and Urbanization 21(1) 185-201. https://doi.org/10.1177/0956247809103016

Ekroos, A. \& Majamaa, V. (2005) Maankäyttö- ja rakennus/aki. Helsinki, Edita.

Eskelinen, T. (2011) Growth - an indicator of the past. Transform! European Journal for Alternative Thinking and Political Dialogue 3 7-14. <https://issuu.com/nextyearcountry/docs/transform newsletter 32011 01>. 23.01.2018. 
Gorz, A. (1979) Ekologi och Politik. Bokomotiv Förlags AB, Stockholm.

Graugaard, J. (2012) A tool for building community resilience? A case study of the Lewes Pound. Local Environment 17 243-260. http://dx.doi.org/10.1080/13549839.2012.660908

Haarstad, H. (2016) Where are urban energy transitions governed? Conceptualizing the complex governance arrangements for low carbon mobility in Europe. Cities 54 4-10. https://doi.org/10.1016/j.cities.2015.10.013

Haarstad, H. \& Oseland, S. E. (2017) Historicizing urban sustainability: the shifting ideals behind Forus Industrial Park, Norway. International Journal of Urban and Regional Research 41(6) 838-854. https://dx.doi.org/10.1111/1468-2427.12551

Harribey, J-M. (2011) Let's talk about money, value and wealth. Transform! European Journal for Alternative Thinking and Political Dialogue 3 21-32. <https://issuu.com/nextyearcountry/docs/ transform newsletter 32011 01>. 23.01.2018.

Heinonen, J. \& Junnila, S. (2012) Yhdyskuntarakenne, elämäntavat ja ilmastonmuutos. Aalto yliopiston julkaisusarja TIEDE+TEKNOLOGIA. Aalto yliopisto, Helsinki.

Hurskainen, A. (2011) Eri esittäjiä: Wanha Jokela. <http://www.desibeli.net/arvostelu/5394>. 26.03.2018.

Jackson, T. (2009) Prosperity without Growth. Earthscan, London.

Joensuu (2012) Joensuun keskustan osayleiskaava, kaavaluonnoksen palauteraportti 16.3.2012. Joensuun kaupunginhallitus, Joensuu.

Joensuu (2013) Lausunto Joensuun keskustan osayleiskaavan hyväksymistä koskevista valituksista. Pöytäkirjanote KH 11/18.3.2013. Joensuun kaupunginhallitus, Joensuu.

Joensuu (2016) Hiilineutraali Joensuu 2015. Joensuun kaupunki, ympäristönsuojelu, Joensuu.

Jokinen, A. (2005) Luonnonvarojen käytön ja dynamiikan hallinta yksityismailla [Control of Use and Dynamics of Natural Resources in Private Land Areas]. Dissertations in Acta Universitatis Tamperensis 1045. University of Tampere, Tampere. http://tampub.uta.fi/bitstream/ handle/10024/67434/951-44-6135-5.pdf?sequence=1

Joutsenvirta, M., Hirvilammi, T., Ulvila, M. \& Wilén, K. (2016) Talous kasvun jälkeen. Gaudeamus, Helsinki.

Kaakinen, I. \& Lehtinen, A. (2016) A bridge that disconnects - on shared and divided socio-spatialities in the pulp mill conflict between Uruguay and Argentina. Forest Policy and Economics 70 101-112. https://doi.org/10.1016/i.forpol.2016.06.005

Kallis, G., Demaria, F. \& D’Alisa, G. (2015) Introduction: degrowth. In Kallis, G., Demaria, F. \& D’Alisa, G. (eds.) Degrowth. A Vocabulary for a New Era, 1-15. Routledge, London.

Kallis, G. \& March, H. (2015) Imaginaries of hope: the utopianism of degrowth. Annals of the Association of American Geographers 105(2) 360-368. http://dx.doi.org/10.1080/00045608.2014.973803

Kamargianni, M., Matyas, M., Li, W. \& Schäfer, A. (2015) Feasibility study for "mobility as a service" concept in London. University College London, London.

Kanninen, V., Kontio, P., Mäntysalo, R. \& Ristimäki, M. (2010) Autoriippuvainen yhdyskunta ja sen vaihtoehdot. Yhdyskuntasuunnittelun tutkimus- ja koulutuskeskuksen julkaisuja B 101. Aalto yliopisto, Espoo.

Kauhanen, H. (2017) Valkoselkätikka Hasanniemessä. Karjalainen 28.12 .2017 <http://edition. pagesuite-professional.co.uk/htm/5/reader/production/default.aspx?pubname=\&edid=bbef2135ad85-4b88-95b9-3f422bd93476>. 10.04.2018.

Kenworthy, J. (2006) The eco-city: ten key transport and planning dimensions for sustainable city development. Environment and Urbanization 18(1) 67-85. https://doi.org/10.1177/0956247806063947

Kortelainen, J. \& Vartiainen, P. (2000) Kohti ekomodernia kaupunkiseutua? In Kortelainen, J. (ed.) Vihertyvä kaupunkiseutu. Suunnittelun ja hallinnan ekomoderni käänne, 9-31. SoPhi, Jyväskylä.

Latouche, S. (2009) Farewell to Growth. Polity Press, Cambridge.

Latouche, S. (2010). Degrowth. Journal of Cleaner Production 18(6) 519-522. https://doi.org/10.1016/j.jclepro.2010.02.003

Lehtinen, A. (1997) Kaupunki riskiympäristönä: liikenneongelma ja pelon maantiede Joensuussa. Terra 109(4) 208-214.

Lehtinen, A. (2012) Politics of decoupling: breaks between indigenous and imported senses of the Nordic North. Journal of Cultural Geography 29(1) 105-123. https://doi.org/10.1080/08873631.2012.655031

Lehtinen, A. (2014a) Ympäristötoimintatutkimus. In Massa, I. (ed.) Polkuja yhteiskuntatieteelliseen ympäristötutkimukseen, 64-76. Gaudeamus, Helsinki.

Lehtinen, A. (2014b) Luonto kaavalaudalla. Ympäristökysymys Joensuun kaupunkisuunnittelussa. In Björn, I. (ed.) Ihmeellinen luonto, 118-131. Pohjois-Karjalan historiallisen yhdistyksen vuosikirja 16. Pohjois-Karjalan historiallinen yhdistys, Joensuu. 
Lehtinen, A. (2017a) Kaupunkisuunnittelu ja kasvun keskittämisen rajat. In Lehtinen, A. \& Pyy, I. (eds.) Mitä on laadullinen kaupunkisuunnittelu?, 67-76. Kunnallisalan kehittämissäätiö, Helsinki.

Lehtinen, A. (2017b) IImastolaskelmat antavat luvan kulutusjuhlaan. Karjalainen 26.11.2017<http:// edition.pagesuite-professional.co.uk/htm/5/reader/production/default. aspx?pubname=\&edid=ce9f829e-b621-4a9a-9be4-d27dd94e3427>. 11.04.2018.

Lehtinen, A. \& Pyy, I. (eds.) (2017) Mitä on laadullinen kaupunkisuunnittelu? Kunnallisalan kehittämissäätiö, Helsinki.

Lietaert, M. (2015) Cohousing's relevance to degrowth theories. Journal of Cleaner Production 18(6) 576-580. https://doi.org/10.1016/j.jclepro.2009.11.016

Mälgand, M, Bay-Mortensen, N., Bedkowska, B., Hansen, F. N., Schow, M., Thomsen, A. A. \& Hunka, A. D. (2014) Environmental awareness, the transition movement, and place: den selvforsynende landsby, a Danish transition initiative. Geoforum 57 40-47. https://doi.org/10.1016/j.geoforum.2014.08.009

McLean, H., Ranking, K. \& Kamikazi, K. (2015) Inner-suburban neighbourhoods, activists research, and the social space of the commercial street. ACME 14(4) 1283-1308. <http://www.acme-journal. org/index.php/acme/article/view/1295>. 13.08.2017.

Nevalainen, J. (2004) Tilapelin tiedonpolitiikat - kamppailu kaupunkikeskustan muutoksesta. Yhteiskuntatieteellisiä julkaisuja 67. Joensuun yliopisto, Joensuu.

Newman, P. \& Kenworthy, J. (1989) Cities and Automobile Dependence. Gover, Aldershot.

North, P. (2010). Eco-localisation as a progressive response to peak oil and climate change - a sympathetic critique. Geoforum 41 585-694. https://doi.org/10.1016/j.geoforum.2009.04.013

OECD (2015) Unemployment rate (indicator). <http://data.oecd.org/unemp/unemploymentrate.htm>. 12.11.2016.

Olli, M. (2012) Hasanniemestä varakkaiden VIP-alue. Karjalainen 25.11.2012

Ottelin, J., Heinonen, J. \& Junnila, S. (2015) New energy efficient housing has reduced carbon footprints in outer but not in inner urban areas. Environmental Science \& Technology $499574-$ 9583. http://pubs.acs.org/doi/10.1021/acs.est.5b02140

Oxfam (2015) Extreme carbon inequality - why the Paris deal must put the poorest, lowest emitting and most vulnerable people first. <http://oxfam.or/sites/www.oxfam.org/files/file_attachment/mbextreme-barboninequality021215-en.pdf>. 10.02.2017.

Papadopoulou, E. (2011) A note on economic growth seen through the prism of the crisis. Transform! European Journal for Alternative Thinking and Political Dialogue 15-22. <https://issuu.com/ nextyearcountry/docs/transform_newsletter_3_2011_01>. 23.01.2018.

PKM (2016) Pohjois-Karjalan HINKU-kunnat. Pohjois-Karjalan Maakuntaliitto, Joensuu. <http:// pohjoiskarjala.fi/web/hinku/hinku-kunnat>. 12.12.2016.

Pyy, I. (2017) Kaupungin laidalla: liitostaajaman kaavoitus ja kehittäminen. In Lehtinen, A. \& Pyy, I. (eds.) Mitä on laadullinen kaupunkisuunnittelu?, 20-33. Kunnallisalan kehittämissäätiö, Helsinki.

Pöysä, P. (2010) Kaksin tekstin kanssa. In Pöysä, J., Järviluoma, H. \& Vakimo, S. (eds.) Vaeltavat metodit, 331-360. Suomen Kansantietouden Tutkijain Seura, Joensuu.

RAC [Regional Administrative Court] (2014) Joensuun keskustan osayleiskaavaa koskevat valitukset. Päätös 14/0019/3 (23.01.2014). Itä-Suomen hallinto-oikeus, Kuopio.

RAC [Regional Administrative Court] (2016) Yleiskaavoitukseen liittyvät valitukset Itä-Suomessa 20132015 (05.01.2016). Itä-Suomen hallinto-oikeus, Kuopio.

Rajaniemi, J. (2006) Kasvun kaavoitus. Tapaus Raahe 1961-1996 [Zoning the growth. Case Raahe 19611996]. Messon, Kankaanpää.

Rannila, P. \& Loivaranta, T. (2015) Planning as dramaturgy: agonistic approaches to spatial enactment. International Journal of Urban and Regional Research 39 788-806. https://dx.doi.org/10.1111/1468-2427.12214

Rautio, T. \& Longi, S. (2013) Oothan vielä. Turha kylä ilman Jokelaa! Dokumenttielokuva hotelliravintola Wanhasta Jokelasta. <https://www.youtube.com/watch?v=VZ8eRp5wnz4>. 12.03.2018.

Said, E. (1991 [1978]) Orientalism. Western Conceptions of the Orient. Penguin Books [Routledge \& Kegan Paul Ltd], London.

Said, E. (1993) Culture and Imperialism. Chatto \& Windus, London.

Sawatzky, M. (2013) Voices in the woods. A study of forest use in Eastern Manitoba. Dissertations in Social Sciences and Business Studies 55. Joensuu, University of Eastern Finland. http://epublications.uef.fi/pub/urn isbn 978-952-61-1085-1/urn isbn 978-952-61-1085-1.pdf

Schneider, F., Kallis, G. \& Martinez-Alier, J. (2010) Crisis or opportunity? Economic degrowth for social equity and ecological sustainability. Journal of Cleaner Production 18(6) 511-518.

https://doi.org/10.1016/j.jclepro.2010.01.014 
Schulz, C. \& Bailey, I. (2014) The green economy and post-growth regimes: opportunities and challenges for economic geography. Geografiska Annaler B 96(3) 277-291. https://dx.doi.org/10.1111/geob.12051

Semi, J. (2017) Osallistumisen epäsymmetria. In Lehtinen, A. \& Pyy, I. (eds.) Mitä on laadullinen kaupunkisuunnittelu?, 34-42. Kunnallisalan kehittämissäätiö, Helsinki.

Sireni, M. (2016) When urban planning doctrine meets low density countryside. European Countryside 3 189-206. https://doi.org/10.1515/euco-2016-0005

VandeWeghe, J. \& Kennedy, C. (2007) A spatial analysis of residential greenhouse gas emissions in the Toronto Census Metropolitan Area. Journal of Industrial Ecology 11(2) 133-144. https://dx.doi.org/10.1162/jie.2007.1220

Victor, P. (2008) Managing without Growth. Slower by Design, Not Disaster. Edward Elgar, Cheltenham. 